\title{
Hormonal profile and body condition scoring in dairy cows during pre partum and post partum periods
}

\author{
Mária Vargová, Vladimír Petrovič, Jana Konvičná, Marián Kadaši, Peter Zaleha, \\ Gabriel Kováč
}

\author{
University of Veterinary Medicine and Pharmacy, Clinic of Ruminants, \\ Košice, Slovak Republic
}

Received September 3, 2014

Accepted November 26, 2014

\begin{abstract}
The aim of this study was to evaluate the dynamics of selected indicators of energy, hormonal profile, body condition score (BCS) and their relationships in dairy cows of the Slovak Pied Cattle from 3 weeks before parturition to 9 weeks after. Significant differences were found in the mean values of non-esterified fatty acids (NEFA) $(P<0.001)$ and $\beta$-hydroxybutyrate $(\mathrm{BHB})$ $(P<0.05)$. According to BCS results, the dry cows were overweight $(4.42 \pm 0.75$ points $)$. After calving the cows lost weight significantly, as the BCS was $3.25 \pm 0.30$ points at 9 weeks post partum $(P<0.001)$. The highest concentration of leptin was recorded before calving $(26.80 \pm 11.47 \mathrm{ng} / \mathrm{ml})$. The concentrations of insulin and ghrelin did not change significantly (an increase in insulin concentrations from $580.8 \pm 66.30 \mathrm{IU} / \mathrm{ml}$ to $625.50 \pm 174.90 \mathrm{IU} / \mathrm{ml}$ and a decrease in ghrelin concentrations from $29.25 \pm 4.82 \mathrm{pg} / \mathrm{ml}$ to $26.57 \pm 5.35 \mathrm{pg} / \mathrm{ml}$ were found comparing 3 weeks to 1 week before parturition, respectively). Relationships between the hormones showed positive correlation between insulin and leptin $(\mathrm{r}=0.220, P<0.05)$, BCS and leptin $(\mathrm{r}=0.360, P<0.001), \mathrm{BCS}$ and insulin $(\mathrm{r}=0.232, P<0.05)$ and negative correlation between leptin and ghrelin $(\mathrm{r}=-0.235, P<0.05)$, BCS and ghrelin $(\mathrm{r}=-0.257, P<0.05)$. These data provide evidence that the variations in the concentrations of leptin, ghrelin, and insulin are related to variations in the BCS. Negative correlation between leptin and ghrelin contributes to the argument that leptin negatively regulates ghrelin.
\end{abstract}

Body condition score, leptin, ghrelin, insulin, cows, periparturient period

The majority of all diseases occur during the period from three weeks before parturition to three weeks after parturition, i.e. in the periparturient or transition period (Bauman 2000). The transition period is associated with a peak incidence of production disease, and the effects of these diseases on dairy cows' health and productivity extend far into the subsequent lactation. These diseases include the fatty liver syndrome, ketosis, alkalosis, oxidative stress, laminitis, mastitis, milk fever, retained placenta, metritis, infertility, etc. Their effects on the production of dairy cows are different, e.g., Illek et al. (1994) found a close relationship between blood values and milk constituents, and a reduction in milk proteins during metabolic alkalosis. The onset of lactation is generally characterised by a negative energy balance (NEB), due to a drastic increase in energy requirements for milk yield and a simultaneous depression in dry mater intake (DMI). The energy status in dairy cows is evaluated by energy intake and output (Rukkwamsuk et al. 1999) and expressed by the body condition score (BCS) (Pavlata et al. 2008). Energy deficiency during lactation causes fat mobilization from the body deposits, increased concentration of nonesterified fatty acids (NEFA) in the blood and increased milk fat synthesis in the mammary gland (Pechová and Pavlata 2005). Metabolic profile indicators are of great importance for early identification of energy metabolism disturbances in cows. Most reliable indicators of the cow's energy status are $\beta$-hydroxybutyrate (BHB) and glucose concentrations during the dry period. Concentrations of these indices are in high correlation with blood NEFA

Address for correspondence:

MVDr. Mária Vargová

Clinic of Ruminants

University of Veterinary Medicine and Pharmacy

Komenského 73, 04181 Košice, Slovak Republic

Phone: +421908 360258

E-mail: mariavargova24@gmail.com

http://actavet.vfu.cz/ 
concentrations and BCS during the peripartal period (Stengärde et al. 2008; Prodanović et al. 2010). Cows lose in body condition during early lactation due to NEB. As a result of NEB, cows have their lowest BCS at approximately one to two months post partum. Several studies have shown that over-conditioned dry cows have a greater depression of feed intake during the peripartal period and deeper NEB than cows with a lower BCS. A number of metabolic hormone concentrations also change over this critical period. Genetic selection for milk production has been associated with a decline in circulating insulin concentrations in dairy cows (Taylor et al. 2003) and insulin concentrations tend to fall in early lactation. In addition, adipose and muscle become insulin resistant in late gestation, but develop an increased sensitivity to lipolytic agents. Changes in insulin play an important role in the metabolic adaptation of cattle to changes in weight and body condition (León et al. 2004).

Changes in the plasma concentration of leptin could also be an important adaptation, particularly given the role of white adipose tissue (WAT) in support of early lactation in dairy cattle. Leptin is involved in the central and/or peripheral regulation of body homeostasis, energy intake, storage and expenditure, fertility and immune functions (Chilliard et al. 2005). Undernutrition or even short-term restriction of access to food results in a significant reduction in leptin concentrations in ruminants (Amstalden et al. 2000). It has been shown that ghrelin may play a role in regulating energy balance (EB). Ghrelin has a role in signalling the deposition of fat tissue by increasing food intake and reducing fat utilization (Bradford and Allen 2008). Leptin acts in opposing fashion to ghrelin by signalling satiation. This causes ghrelin to be expressed at lower concentrations during states of positive EB and increased during NEB (Nogueiras et al. 2008). The aim of this study was to determine the plasma concentrations of hormonal profile indicators: leptin, insulin, ghrelin and selected variables of the energy profile: NEFA, glucose and $\mathrm{BHB}$, their changes in relation to the peripartal period; evaluation of BCS which was changed due to NEB and assessment of their relationships.

\section{Materials and Methods}

Selected indicators of the hormonal profile - leptin, ghrelin, insulin; energy profile - NEFA, glucose, BHB, and body condition score were evaluated in dairy cows (aged 3-5 years) of the Slovak Pied Cattle breed from April to August 2013. Dairy cows $(n=15)$ were classified into different groups based on the calving date (according to certain phases of ante partum (a.p.) and post partum (p.p.). The animals were divided individually into 6 groups:

Group 1 - dairy cows 3 weeks before parturition

Group 2 - dairy cows 1 week before parturition

(3 wk a.p.)

$(\mathrm{n}=15)$

(1 wk a.p.)

$(\mathrm{n}=15)$

(1 wk p.p.)

$(\mathrm{n}=15)$

(3 wk p.p.)

$(\mathrm{n}=15)$

Group 4 - dairy cows 3 weeks after parturition

(6 wk p.p.)

(9 wk p.p.)

$(\mathrm{n}=15)$

$(\mathrm{n}=15)$

Group 6 - dairy cows 9 weeks after parturition

The mean production age was 2.5 lactations. The milk yield during the previous lactation was $6668.5 \mathrm{~kg}$ of milk during a 305-day lactation. The animals were fed a total mixed ration (TMR) twice daily, nutrient composition of the TMR varied with the stage of pregnancy and lactation (Table 1). The dairy cows had free access to drinking water. The experiment was carried out in accordance with the established standards for animal care and use on a farm near Košice. The protocol was approved by the Ethics Committee of the University of Veterinary Medicine and Pharmacy in Košice, Slovak Republic (14/2014). All the evaluated variables were analysed in blood serum. The blood samples were collected $3 \mathrm{~h}$ after feeding by direct puncture of $\mathrm{v}$. jugularis. The concentrations of NEFA (Randox, UK) was assessed by spectrophotometric method - Specord 210 Plus (Analytik Jena, Germany). The concentrations of BHB and glucose were determined using commercial diagnostic kits (Randox, UK) on automatic biochemical analyser Alizé (Lisabio, France). Insulin (IU/ml) was determined by ELISA using commercial assays (Cusabio, China) according to the manufacturer's instructions. The concentrations of leptin $(\mathrm{ng} / \mathrm{ml})$ and ghrelin $(\mathrm{pg} / \mathrm{ml})$ were determined by RIA kits from Millipore (St. Charles, Missouri, USA) according to the manufacturer's instructions. The body condition score was determined using a 5-point scale and backfat thickness (BFT) measurements were obtained using a $3.5 \mathrm{MHz}$ linear transducer. The body condition score (BCS) and BFT were assessed according to Staufenbiel (1997). The examination site was located in the sacral region between the caudal one-quarter and one-fifth connection line going from the dorsal part of the tuber ischia (pins) to the tuber coxae (hooks). This site corresponds to the area between the end of the crista sacralis and the end of the os sacrum (i.e., beginning of the first coccygeal vertebra). Results for BCS are presented as mean BCS and 
Table 1. Components of prepartum and postpartum diets ( $\mathrm{kg} / \mathrm{head} / \mathrm{day})$.

\begin{tabular}{lccccc}
\hline & 3-1 wk a.p. & 1wk p.p. & 3 wk p.p. & 6 wk p.p. & 9 wk p.p. \\
\hline Meadow hay & 5.5 & 1.5 & 1.5 & 1.5 & 1.5 \\
R24 & 0.3 & 0.25 & 0.3 & 0.25 & 0.25 \\
Haylage & 4 & 4 & 6 & 6 & 6 \\
Lucerne silage & 13 & 24 & 22 & 22 & 22 \\
Green fodder & & 25 & 25 & 25 & 25 \\
Soybean meal & & 0.8 & 0.8 & & \\
Rape meal & & 3 & 2.5 & 2.5 & 2.5 \\
Wheat meal & & 0.2 & 0.2 & 2.5 & \\
Limestone & & & 0.5 & 0.2 & 0.2 \\
Flaxseed meal & & & & 1 & 1 \\
Maize meal & & & & & 3.5 \\
Triticale & & & & & \\
\hline
\end{tabular}

R-24 - mineral supplement $(10.4 \% \mathrm{Ca}, 9 \% \mathrm{P}, 11 \% \mathrm{Na}, 4 \% \mathrm{Mg}, 7000 \mathrm{mg} \mathrm{Cu}, 3000 \mathrm{mg}$ inorganic $\mathrm{Mn}, 6000 \mathrm{mg}$ inorganic Zn, $40 \mathrm{mg} \mathrm{Se}, 100 \mathrm{mg} \mathrm{I}, 20 \mathrm{mg} \mathrm{Co}, 1000000 \mathrm{IU}$ vitamin A, 100000 IU vitamin D3, 2000 IU vitamin E)

as digression from physiological values at examined periods. Animals were scored for body condition on the day of their blood collection. Evaluation of the obtained results was performed by the assessment of mean values (x) and standard deviations (S.D.) in each monitored group of dairy cows. Significance of differences in the mean values in relation to the several monitored periods was evaluated by one way analysis of variance (ANOVA). Significance of differences in the mean values between groups was evaluated by Tukey's multiple comparisons test. Pearson's correlation coefficients were calculated to describe relationships between the monitored variables, relationships were evaluated by linear regression analysis, including significance of the correlation at the same time. Statistical analyses were done with the GraphPad Prism 3.0 software.

\section{Results}

Concentrations of metabolic hormones (leptin, ghrelin, and insuline) in blood serum during prepartal and postpartal periods are presented in Figs 1, 2 and 3. Body condition scoring results are shown in Table 2. Concentrations of selected metabolites of the energy

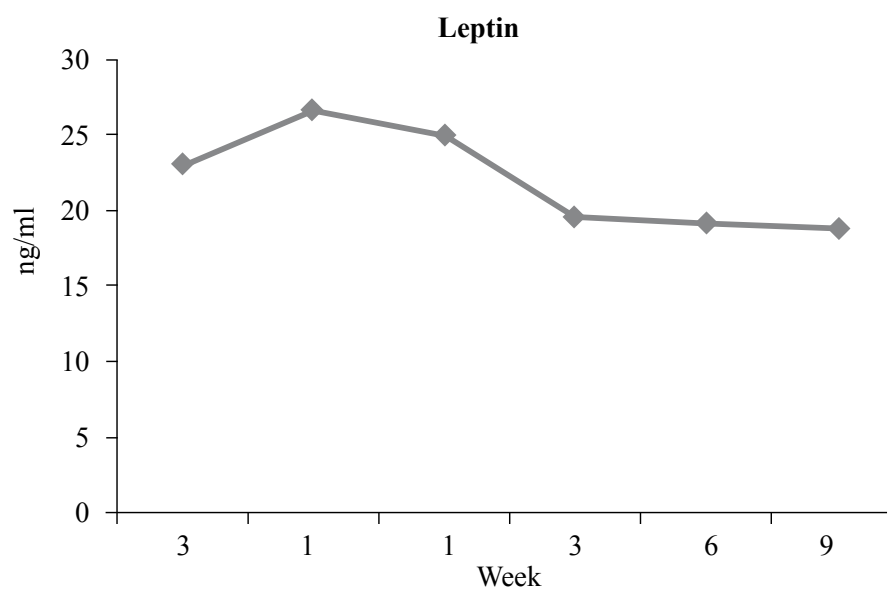

Fig. 1. Mean concentrations of leptin in the monitored groups of dairy cows during prepartal and postpartal periods 


\section{Ghrelin}

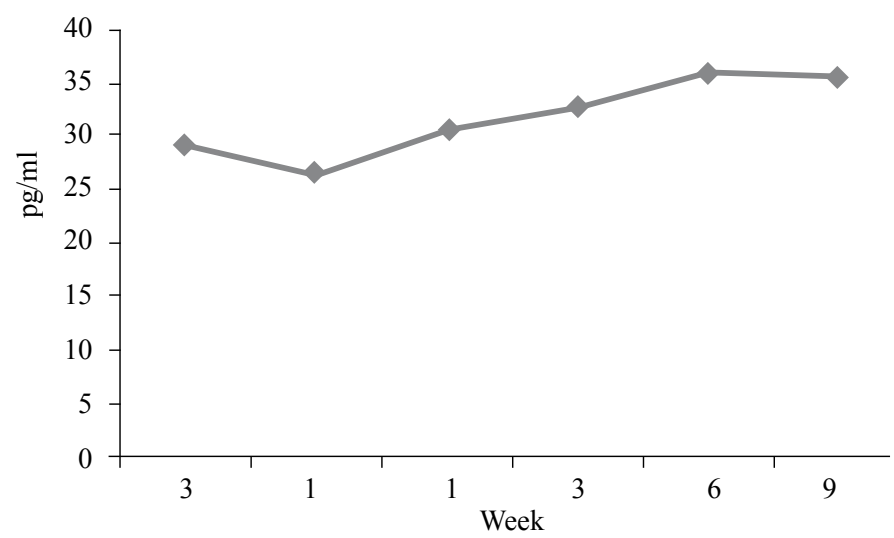

Fig. 2. Mean concentrations of ghrelin in the monitored groups of dairy cows during prepartal and postpartal periods

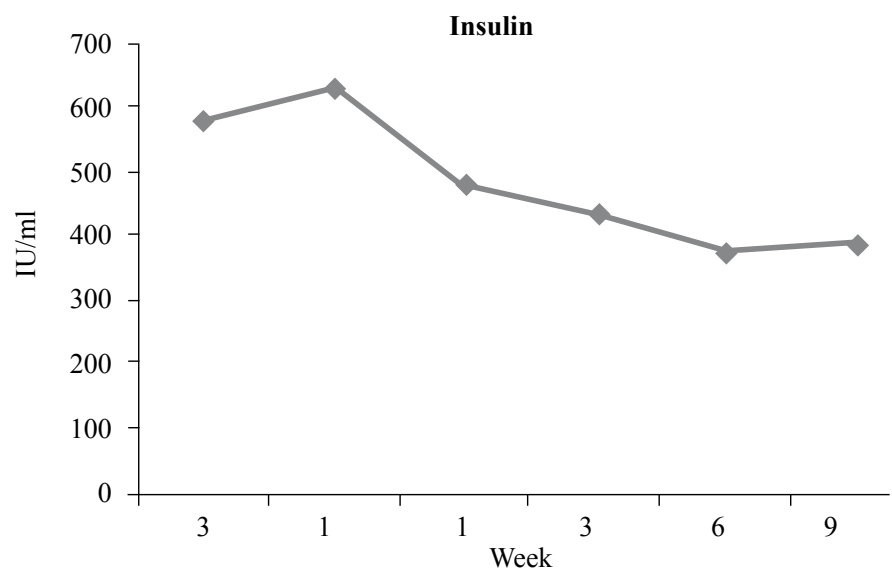

Fig. 3. Mean concentrations of insulin in the monitored groups of dairy cows during prepartal and postpartal periods

profile that were achieved after analyses of blood samples are shown in Table 3. Correlation between the concentration of plasma leptin and BCS is shown in Fig. 4; correlation between the concentration of ghrelin and leptin is shown in Fig. 5; correlation between the concentration of insulin and leptin is shown in Fig. 6; correlation between the concentration of ghrelin and BCS is shown in Fig. 7; and correlation between the concentration of insulin and BCS is shown in Fig. 8.

The concentrations of leptin during the a.p. increased from $23.08 \pm 10.58 \mathrm{ng} / \mathrm{ml}$ (Group 1) to $26.80 \pm 11.47 \mathrm{ng} / \mathrm{ml}$ (Group 2$)$ then gradually decreased $(P>0.05)$. Ghrelin concentrations before parturition were found to be decreasing, in the early postpartal period the concentrations increased and the highest value $(35.94 \pm 16.85 \mathrm{pg} / \mathrm{ml})$ was recorded 6 weeks after parturition. In the case of insulin we found an opposed tendency, the 
Table 2. Mean values of the body condition score at different stages.

\begin{tabular}{|c|c|c|c|c|c|c|c|}
\hline BCS & $\begin{array}{l}3 \mathrm{wk} \\
\text { a.p. }\end{array}$ & $\begin{array}{l}1 \mathrm{wk} \\
\text { a.p. }\end{array}$ & $\begin{array}{l}1 \mathrm{wk} \\
\text { p.p. }\end{array}$ & $\begin{array}{l}3 \mathrm{wk} \\
\text { p.p. }\end{array}$ & $\begin{array}{l}6 \mathrm{wk} \\
\text { p.p. }\end{array}$ & $\begin{array}{l}9 \text { wk } \\
\text { p.p. }\end{array}$ & $P$ \\
\hline $\mathrm{x}$ & $4.42^{\mathrm{ABC}}$ & $4.25^{\mathrm{aDE}}$ & $3.90^{\alpha \beta}$ & $3.48^{\mathrm{Aa}}$ & $3.35^{\mathrm{BD} \alpha}$ & $3.25^{\mathrm{CE} \beta}$ & $<0.001$ \\
\hline SD & 0.75 & 0.58 & 0.45 & 0.51 & 0.40 & 0.30 & \\
\hline
\end{tabular}

Results are presented as mean $\pm \mathrm{SD}(\mathrm{n}=15)$. The same indices in lines represent significance of differences in the mean values between the groups: $P<0.05-\alpha, \beta ; P<0.01-\mathrm{a} ; P<0.001-\mathrm{A}, \mathrm{B}, \mathrm{C}, \mathrm{D}, \mathrm{E}$

$P$ - significance of the differences of the results during monitored time

wk - weeks before and after parturition

a.p.- ante partum

p.p. - post partum

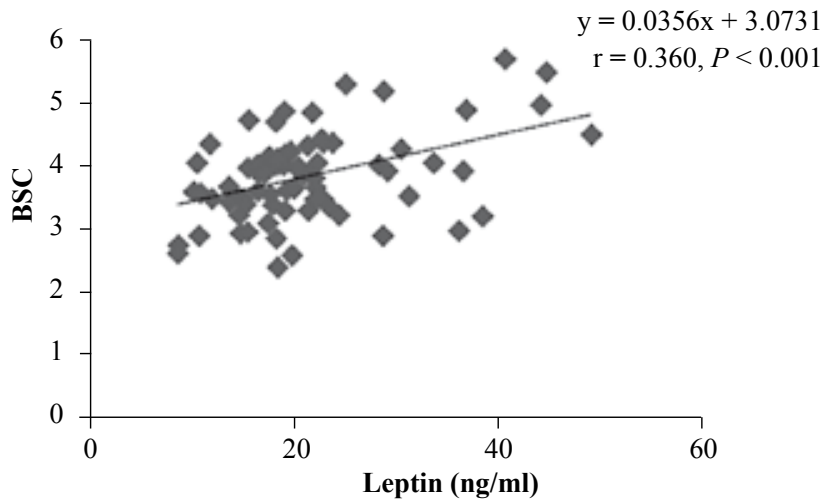

Fig. 4. Correlation between the concentrations of plasma leptin and BCS ante partum and post partum $(\mathrm{n}=90)$

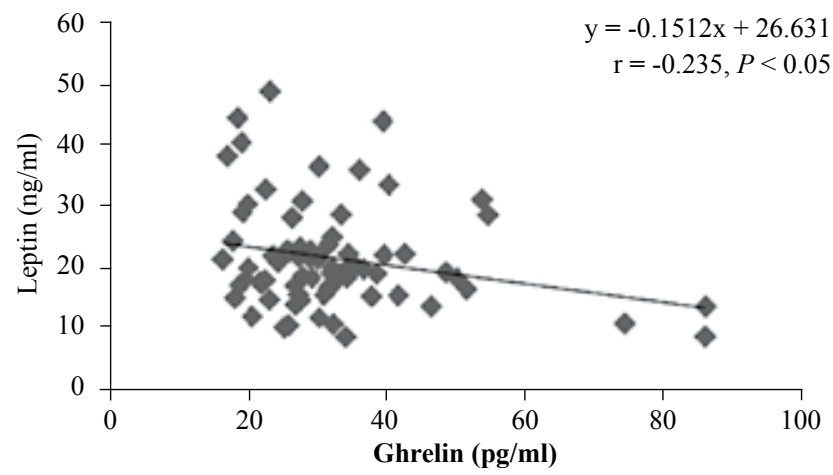

Fig. 5. Correlation analysis between the concentrations of ghrelin and leptin ante partum and post partum $(\mathrm{n}=90)$

concentrations in the time before calving were higher (from $580.8 \pm 66.3$ to $625.5 \pm 174.9$ $\mathrm{IU} / \mathrm{ml}$ ) than the values recorded after calving (from $483.3 \pm 289.0$ to $388.7 \pm 172.5 \mathrm{IU} / \mathrm{ml}$ ). The differences in average values of insulin concentrations during a.p. and p.p. periods in the monitored groups were not significant. 


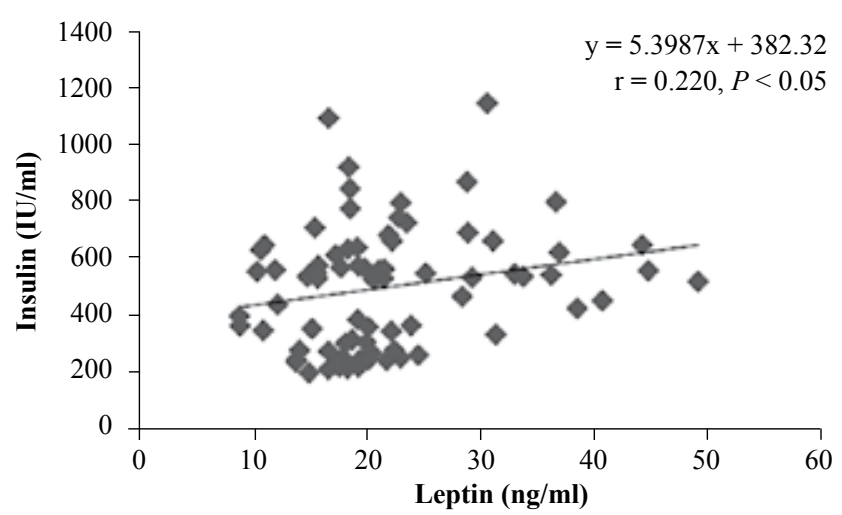

Fig. 6. Correlation analysis between the concentrations of insulin and leptin ante partum and post partum $(\mathrm{n}=90)$

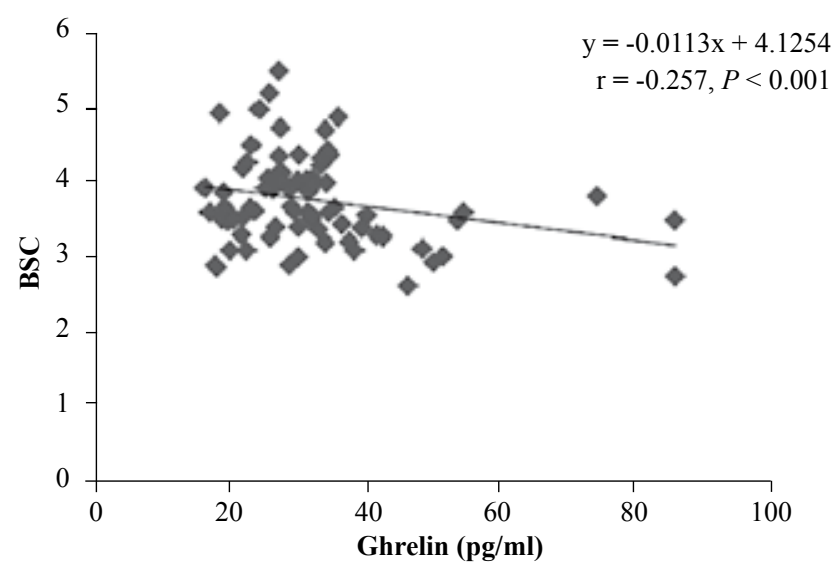

Fig. 7. Correlation analysis between the concentrations of ghrelin and BCS ante partum and post partum $(\mathrm{n}=90)$

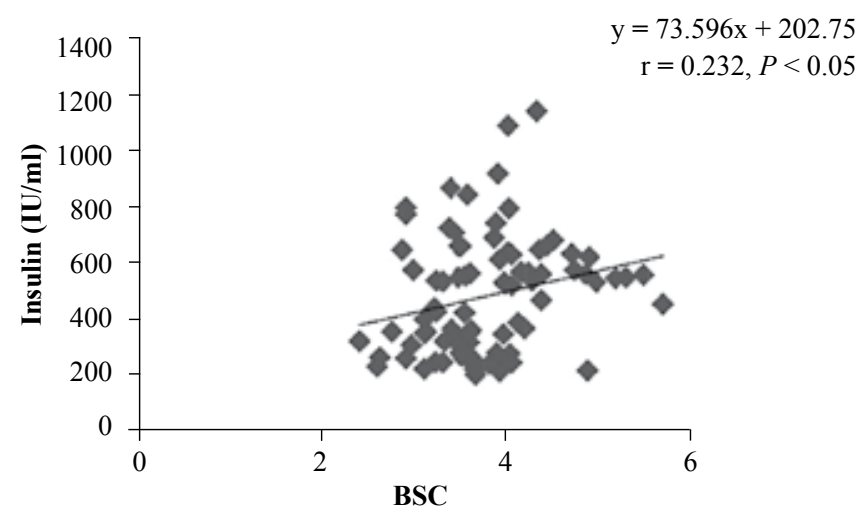

Fig. 8. Correlation analysis between the concentrations of insulin and BCS ante partum and post partum $(\mathrm{n}=90)$ 
Table 3. Concentrations of selected metabolites of the energy profile in dairy cows during the prepartal and postpartal periods.

\begin{tabular}{|c|c|c|c|c|c|c|c|c|}
\hline Indicator & & 3 wk a.p. & 1 wk a.p. & 1 wk p.p. & 3 wk p.p. & 6 wk p.p. & 9 wk p.p. & $P$ \\
\hline \multirow{2}{*}{$\begin{array}{l}\text { Glucose } \\
(\mathrm{mmol} / \mathrm{l})\end{array}$} & $\mathrm{x}$ & 3.97 & 3.83 & 3.40 & 3.70 & 3.90 & 3.88 & ns \\
\hline & SD & 0.19 & & 1.13 & 0.40 & 0.44 & 0.38 & 0.27 \\
\hline NEFA & $\mathrm{x}$ & $0.44^{\mathrm{AB}}$ & $1.29^{\mathrm{A \alpha C}}$ & $1.69^{\mathrm{BDEF}}$ & $0.93^{\mathrm{D}}$ & $0.73^{\alpha \mathrm{E}}$ & $0.51^{\mathrm{CF}}$ & $<0.001$ \\
\hline$(\mathrm{mmol} / \mathrm{l})$ & SD & 0.190 .78 & 0.55 & 0.39 & 0.27 & 0.23 & & \\
\hline BHB & $\mathrm{x}$ & 0.40 & 0.69 & 0.72 & 0.83 & 0.54 & 0.39 & $<0.05$ \\
\hline$(\mathrm{mmol} / \mathrm{l})$ & $\mathrm{SD}$ & 0.12 & 0.33 & 0.29 & 0.89 & 0.28 & 0.17 & \\
\hline
\end{tabular}

Results are presented as mean \pm standard deviation $(\mathrm{n}=15)$. The same indices in lines mean significance of differences in the mean values between the groups: $P<0.05-\alpha ; P<0.001-\mathrm{A}, \mathrm{B}, \mathrm{C}, \mathrm{D}, \mathrm{E}, \mathrm{F}$

$P$ - significance of the differences of the results during monitored time

wk - weeks before and after parturition

NEFA - non-esterified fatty acids

BHB - $\beta$-hydroxybutyrate

a.p.- ante partum

p.p. - post partum

ns - not significant

Table 2 shows that the mean BCS 3 wk a.p. was above the reference values. During the postparturient period we found the BCS gradually decreasing from $3.90 \pm 0.45$ to $3.25 \pm$ 0.30 points with significance. Mean BCSs in dairy cows 3 and 1 wk a.p. were significantly higher than at 3 weeks p.p. $(P<0.001)$ and the BCS in cows 3 weeks a.p. was significantly higher than in cows 9 weeks p.p. $(P<0.001$ and $P<0.01)$.

Glucose concentrations remained within the physiological range; cows after calving (1 week p.p.) exhibited the lowest concentration of glucose. In NEFA concentrations (Table 3) significantly lower values were observed in the cows 3 wk a.p. and 6, 9 wk p.p. than those determined in the cows 1 wk a.p. and 1 wk p.p. $(P<0.001$ and $P<0.05)$. The concentrations of BHB from 3 wk a.p. to 3 wk p.p. increased from $0.40 \pm 0.12$ to $0.83 \pm$ $0.89 \mathrm{mmol} / \mathrm{l}$ and then gradually decreased.

In our study (Fig. 4) leptin and BCS were in significant positive correlation $(\mathrm{r}=0.360$, $P<0.001)$; also insulin and BCS (Fig. 8) were in significant positive correlation $(\mathrm{r}=0.232$, $P<0.05)$. The BCS and ghrelin were negatively correlated $(\mathrm{r}=-0.257, P<0.05)$ (Fig. 7). By evaluation of correlation between leptin and ghrelin we found negative correlation $(\mathrm{r}=-0.235, P<0.05)$ (Fig. 5). By assessment of correlation (Fig. 6) between insulin and leptin we recorded their significant positive correlation $(\mathrm{r}=0.220, P<0.05)$.

\section{Discussion}

The transition from pregnancy to lactation in dairy cows is associated with a reduction in the plasma concentration of leptin. It is likely to promote centrally mediated adaptations required in periods of energy deficit. We observed non-significantly lower concentrations of leptin during the post partum than during the ante partum. Reduced synthesis of leptin in WAT is largely responsible for the lower concentration of plasma leptin in early lactating dairy cows. This reduction could benefit early lactating dairy cows by promoting a faster increase in feed intake and by diverting energy from non-vital functions such as reproduction (Block et al. 2001). Circulating ghrelin concentrations increase during fasting or NEB in dairy cows, and exogenous administration of ghrelin stimulates feed intake in rats and cattle (Wren et al. 2000; Wertz-Lutz et al. 2006; Bradford and Allen 2008). Although we did 
not detect a significant difference in plasma ghrelin concentrations over time in our study, we did observe a trend for the lowest concentrations in the dairy cows 1 week a.p. and the highest concentrations in the cows 6 weeks p.p. The highest value of ghrelin in the dairy cows immediately after calving is associated to changes in feed intake and the initiation of lactogenesis. Changes in insulin play an important role in the metabolic adaptation of cattle to changes in the weight and body condition (Leon et al. 2004). Our data indicate that insulin concentration was non-significantly different in dried cows compared to post partum dairy cows. It seems that the blood insulin concentration varied widely from the $1^{\text {st }}$ to the $3^{\text {rd }}$ week post partum. Similarly, gradual increase of this index was observed during the progressing lactation (Illek et al. 2009). Our data also indicate that insulin blood concentration decreases from the dry period (1 week a.p.) towards early lactation (1 week p.p.) A decrease in insulin blood concentration at calving is a metabolic adaptation to cope with the energy demands of lactation (Taylor et al. 2003; Wathes et al. 2007), as low insulin concentrations favour gluconeogenesis and lipolysis (Herdt 2000). Insulin is also a putative mediator of the nutritional status. However, the process of adaptation to the NEB in dairy cows is usually accompanied with a decrease of blood insulin (Jorritsma et al. 2003; Hammon et al. 2009; Wathes et al. 2011).

Cows with high BCS before calving had greater risks of metabolic problems because of excessive mobilization of body reserves resulting in metabolic disorders with devastating effects on health, production and reproduction of these animals. High rates of BCS loss in the early postpartal period are associated with severe NEB, alterations in blood metabolites and hormone profiles (Wathes et al. 2007). Cows with optimal BCS at calving had higher insulin concentrations in the postpartal period and adapted better than cows with a high BCS at calving (over-conditioned) to increased energy requirements after parturition. According to BCS results dry cows in this study were overweight (4.42 \pm 0.75 points) because the physiological range of BCS for Slovak Pied Cattle is 3.25 to 3.75 (dry period), 3.25 to 3.75 (puerperium) and 2.50 to 3.0 (the first 100 days of lactation) (Strapák et al. 2004). Although there were no visible signs of health disorders, selected indicators of the energy profile and body condition scoring obtained in this work showed that the cows suffered from NEB during the post partum period. The decrease in glucose concentrations in puerperal dairy cows previously reported in different studies (Veenhuizen et al. 1991; Drackley et al. 2001; Dann et al. 2005), may be related to the sudden activity of the mammary gland and increased lactose synthesis. Furthermore, the NEB associated with lipomobilization and increased fat accumulation in hepatocytes may induce a considerable reduction in the liver gluconeogenesis, also contributing to reduction of glycaemia. A pre partum rise in NEFA suggested that the cows were already in NEB at this time and were mobilizing lipids as an energy source (Duffield 2000). According to Bernabucci et al. (2005) increased circulating NEFA concentrations are directly associated with large amounts of adipose stores during a time of energy deficiency. The increase in NEFA is generally of short duration $(<5$ weeks), but our results showed that the NEFA peak remained high longer. Decreased concentrations of NEFA in dairy cows 9 weeks after calving indicate that NEB is gradually corrected by reduction of lipomobilization as a direct indicator of NEB. Serum $\mathrm{BHB}$ concentration is another indicator of energy metabolism disruptions which is more sensitive than glycaemia and which fluctuates in parallel to lipomobilization (Veenhuizen et al. 1991). Increasing concentrations of ketones are thought to suppress the feed intake. Cows with high values of BHB have lower reproductive capacity, significant loss in body condition, produce a small amount of milk and suffer from extreme metabolic changes (Kessel et al. 2008). The increased value of BHB indicates the possibility of fatty liver, which can affect the process of metabolic adaptation (Šamanc et al. 2011).

Our data confirm the strong link between leptin and BCS. Ehrhardt et al. (2000) estimated that BCS in late pregnant cows explained $37 \%$ of the variation in plasma leptin. 
Reist et al. (2003) also observed a positive relationship between BCS and plasma leptin, whereas Holtenius et al. (2003) did not. Our results are in agreement with previous studies showing that plasma leptin was positively correlated with BCS in cows during lactation (Ehrhardt et al. 2000). These results, in addition to those obtained recently in adult sheep (Blache et al. 2000; Delavaud et al. 2000), confirm that plasma leptin in ruminants is related to body fat, as previously observed in humans and rodents (Maffei et al. 1995). Ghrelin concentrations were negatively correlated with changes in BCS, indicating that as BCS decreased, plasma ghrelin concentrations increased. Leptin negatively regulates ghrelin, and the increases of ghrelin induced by weight loss arise because of diminished inhibitory input from leptin. If valid, this interpretation could imply that the weightreducing effects of leptin are mediated not only via direct central actions, but also via peripheral inhibition of ghrelin. The hypothesis that leptin negatively regulates ghrelin also predicts that conditions of excessive leptin signalling should be associated with low ghrelin concentrations and vice versa. In this study, leptin concentrations decreased after calving, meanwhile ghrelin concentrations increased. The significant correlations between plasma concentrations of leptin and insulin could represent co-regulation by EB, and perhaps a role for these factors in mediating the effect of EB on leptin synthesis. We observed significant positive correlation between leptin and insulin. Insulin upregulates leptin expression in vivo and in vitro in bovine WAT explants. These effects of insulin are dependent on adequate uptake of glucose, suggesting that cellular energy availability is the primary factor regulating leptin synthesis (Wellhoener et al. 2000). Our results are in agreement with previous studies showing that plasma insulin was positively correlated with BCS (Vizcarra et al. 1998). However, in the study of León et al. (2004), the rate of increase in insulin differed as heifers achieved a higher BCS.

In conclusion, our results demonstrate that variables of hormonal profile such as leptin, ghrelin and insulin, and the indicators of the energy profile such as NEFA, BHB and glucose changed throughout the time around calving, which suggests that they have a physiological role in the dairy cow's energy metabolism. Reduction in plasma leptin during the postpartal period could benefit early lactating dairy cows by promoting a faster increase in the feed intake and by diverting energy from non-vital functions such as reproduction. The presented results also showed positive or negative relationships between indicators of hormonal profile and body condition.

\section{Acknowledgements}

This work was supported by Slovak Research and Development Agency under contract No. APVV-0475-10 and by VEGA Scientific Grant No.1/0592/12 from the Ministry of Education.

\section{References}

Amstalden M, Garcia MR, Williams SW, Stanko RL, Nizielski SE, Morison CD, Keisler DH, Williams GL 2000: Leptin gene expression, circulating leptin, and luteinizing hormone pulsatility are acutely responsive to shortterm fasting in prepubertal heifers: relationships to circulating insulin and insulin-like growth factor I. Biol Reprod 63: 127-133

Bauman DE 2000: Regulation of nutrient partitioning during lactation: Homeostasis and homeorhesis revisited. In: Cronjé PB (Ed.): Ruminant Physiology: Digestion, Metabolism, Growth, and Reproduction. CABI Pub, Wallingford, Oxon, UK; New York, NY, USA, pp. 311-328

Bernabucci U, Ronchi B, Lacetera N, Nardone A 2005: Influence of body condition score on relationships between metabolic status and oxidative stress in periparturient dairy cows. J Dairy Sci 88: 2017-26

Blache D, Tellam RL, Chagas LM, Blackberry MA, Vercoe PE, Martin GB 2000: Level of nutrition affects leptin concentrations in plasma cerebrospinal fluid in sheep. J Endocrinol 165: 625-637

Block SS, Butler WR, Ehrhardt RA, Bell AW, Van Amburgh ME, Boisclair YR 2001: Decreased concentration of plasma leptin in periparturient dairy cows is caused by negative energy balance. J Endocrinol 171: 339-48

Bradford BJ, Allen MS 2008: Negative energy balance increases periprandial ghrelin and growth hormone concentrations in lactating dairy cows. Domest Anim Endocrin 34: 196-203 
Dann HM, Morin DE, Murphy MR, Bollero GA, Drackley JK 2005: Prepartum intake, postpartum induction of ketosis, and periparturient disorders affect the metabolic status of dairy cows. J Dairy Sci 88: 3249-3264

Delavaud C, Bocquier F, Chilliard Y, Keisler DH, Gertler A, Kann G 2000: Plasma leptin determination in ruminants: Effect of nutritional status and body fatness on plasma leptin concentration assessed by a specific RIA in sheep. J Endocrinol 165: 519-526

Drackley JK, Overton TR, Douglas GN 2001: Adaptations of glucose and long-chain fatty acid metabolism in liver of dairy cows during the periparturient period. J Dairy Sci 84: 100-112

Duffield T 2000: Subclinical ketosis in lactating dairy cattle. Metab Disord Rumin 16: 231-253

Ehrhardt RA, Slepetis RM, Siegal-Willott J, Van Amburgh ME, Bell AW, Boisclair YR 2000: Development of a specific radioimmunoassay to measure physiological changes of circulating leptin in cattle and sheep. $\mathrm{J}$ Endocrinol 166: 519-528

Hammon HM, Sturmer G, Schneider F, Tuchscherer A, Blum H, Engelhard T 2009: Performance and metabolic and endocrine changes with emphasis on glucose metabolism in high-yielding dairy cows with high and low fat content in liver after calving. J Dairy Sci 92: 1554-1566

Herdt T 2000: Ruminant adaptation to negative energy balance: influence on the etiology of ketosis and fatty liver. Metabolic disorders of ruminants. Vet Clin North Am, Food Anim Pract 16: 215-30

Holtenius K, Agenäs AS, Delavaud C, Chilliard Y 2003: Effects of feeding intensity during the dry period. 2. Metabolic and hormonal responses. J Dairy Sci 86: 883-891

Chilliard Y, Delavaud C, Bonnet M 2005: Leptin expression in ruminants: Nutritional and physiological regulations in relation with energy metabolism. Domest Anim Endocrin 29: 3-22

Illek J, Fleischer P, Suchý, P, Pechova A, Zendulka I 1994: Effect of metabolic alkalosis on the composition and quality of milk. In: Abstracts of $7^{\text {th }}$ Satellite Symposium, ISRP, Slovakia, Stara Lesna, 2-5 ${ }^{\text {th }}$ October 1994

Illek J, Kumprechtova D, Matejicek M, Vlcek M 2009: Metabolic profile in high-producing dairy cows in different phases of the calving-to-calving interval. Folia Vet 1: 73

Jorritsma R, Wensing T, Kruip TA, Vos PL, Noordhuizen JP 2003: Metabolic changes in early lactation and impaired reproductive performance in dairy cows. Vet Res 34: 11-26

Kessel S, Stroehl M, Meyer HHD, Hiss S, Sauerwein H, Schwarz FJ 2008: Individual variability in physiological adaptation to metabolic stress during early lactation in dairy cows kept under equal conditions. J Anim Sci 86: 2903-2912

León HV, Hernández-Cerón J, Keisler DH, Gutierrez CG 2004: Plasma concentrations of leptin, insulin-like growth factor-I, and insulin in relation to changes in body condition score in heifers. J Anim Sci 82: 445-451

Maffei M, Halaas J, Ravussin E, Pratley RE, Lee GH, Zhang Y, Fei H, Kim S, Lallone R, Ranganathan S, Kern PA, Friedman JM 1995: Leptin levels in human and rodent: Measurement of plasma leptin and ob RNA in obese and weight-reduced subjects. Nat Med 1:1155-1161

Nogueiras R, Tschop MH, Zigman JM 2008: Central nervous system regulation of energy metabolism: Ghrelin versus leptin. Ann Ny Acad Sci 1126: 14-19

Pavlata L, Antoš D, Pechová A, Podhorsky A 2008: Metabolic abnormalities of vitamin E and their diagnostics and therapy in cattle (in Czech). Veterinářství 58: 37-42

Pechova A, Pavlata L 2005: The use of metabolic profiles in the control of nutrition of dairy cows. In: Dvořák R (Ed.): Nutrition of Cattle in Terms of Production and Preventive Medicine (in Czech). Noviko, Brno, pp. $102-111$

Prodanović R, Kirovski D, Jakić-Dimić D, Vujanac I, Kureljušić B 2010: Body condition and indicators of energy status of cows in late pregnancy and early lactation stage. Vet Glasnik 63: 43-52

Reist M, Erdin DK, Von Euw D, Tschümperlin KM, Leuenberger H, Hammon HM, Morel C, Philipona C, Zbinden Y, Künzi N, Blum JW 2003: Postpartum reproductive function: association with energy, metabolic and endocrine status in high yielding dairy cows. Theriogenology 59: 1707-1723

Rukkwamsuk T, Wensing T, Kruip TAM 1999: Relationship between triacylglycerol concentration in the liver and first ovulation in postpartum dairy cows. Theriogenology 51: 1133-1142

Staufenbiel R 1997: Condition assessment of dairy cows using the ultrasound backfat thickness measurement (in German). Pract Veterinary Coll Vet 27: 87-92

Stengärde L, Traven M, Emanuelson U, Holtenius K, Hultgren J, Niskanen R 2008: Metabolic profiles in five high-producing Swedish dairy herds with a history of abomasal displacement and ketosis. Acta Vet Scand 50: 31

Strapák P, Juhás P, Strapáková E, Bujko J, Žitný J, Čanji V 2004: Evaluation of body condition scoring of Slovak Spotted cattle. Acta fytotechnica et zootechnica 3: 72-77

Šamanc H, Kirovski D, Stojič V, Stojanovič D, Vujanac I, Prodanovič R 2011: Application of the metabolic profile test in the prediction and diagnosis of fatty liver in Holstein cows. Acta Vet-Beograd 61: 543-53

Taylor VJ, Beever DE, Wathes DC 2003: Physiological adaptations to milk production that affect fertility in high yielding dairy cows. British Society of Animal Science Occ Pub 29: 37-71

Veenhuizen JJ, Drackley JK, Richard MJ, Sanderson TP, Miller LD, Joung JW 1991: Metabolic changes in blood and liver during development and early treatment of experimental fatty liver and ketosis in cows. J Dairy Sci 74: 4238-4253

Vizcarra JA, Wettemann RP, Spitzer JC, Morrison DG 1998: Body condition at parturition and postpartum weight 
gain influence luteal activity and concentrations of glucose, insulin, and nonesterified fatty acids in plasma of primiparous beef cows. J Anim Sci 76: 927-936

Wathes D, Cheng Z, Bourne N, Taylor V, Coffey M, Brotherstone S 2007: Differences between primiparous and multiparous dairy cows in the interrelationships between metabolic traits, milk yield and body condition score in the periparturient period. Domest Anim Endocrin 33: 203-25

Wathes DC, Cheng Z, Fenwick MA, Fitzpatrick R, Patton J 2011: Influence of energy balance on the somatotrophic axis and matrix metalloproteinase expression in the endometrium of the postpartum dairy cow. Reproduction 141: $269-81$

Wellhoener P, Fruehwald-Schultes B, Kern W, Dantz D, Kerner W, Born J, Fehm HL, Peters A 2000: Glucose metabolism rather than insulin is a main determinant of leptin secretion in humans. J Clin Endocr Metab 85: 1267-1271

Wertz-Lutz AE, Knight TJ, Pritchard RH, Daniel JA, Smart AJ, Trenkle A, Beitz DC 2006: Circulating ghrelin concentrations fluctuate relative to nutritional status and influence feeding behavior in cattle. J Anim Sci 84: 3285-3300

Wren AM, Small CJ, Ward HL, Murphy KG, Dakin CL, Taheri S, Kennedy AR, Roberts GH, Morgan GA, Ghatei MA, Bloom SR 2000: The novel hypothalamic peptide ghrelin stimulates food intake and growth hormone secretion. Endocrinology 141: 4325-4328 